(c) American Dairy Science Association, 2003.

\title{
Technical Note: Calibration of a Simple Udder Volume Measurement Technique
}

\author{
H. Magaña-Sevilla and C. A. Sandoval-Castro \\ Facultad de Medicina Veterinaria y Zootecnia, \\ Universidad Autónoma de Yucatán, \\ km 15.5 Mérida-Xmatkuil, 97100 \\ Yucatán, México
}

\begin{abstract}
A simple technique to measure udder volume in dairy cows using aluminum foil was developed and used to characterize empty udder volume (EUV) in a dual purpose herd (Bos taurus $\times$ B. indicus). The technique was calibrated by comparing cows' actual milk yield with the difference between its EUV and full udder volume (FUV). The resulting relationship was: Actual milk volume $=0.718( \pm 0.9568)+0.954( \pm 0.0775) *$ (Calculated milk volume), $\mathrm{R}^{2}=0.949$. In 24 lactating cows, EUV was correlated with calving number and milk yield. Estimated mammary parenchyma productivity was $1.85 \pm 0.117 \mathrm{ml} / \mathrm{L}$ of EUV. The technique developed is a quick, cheap and yet precise alternative to measure udder volume.
\end{abstract}

(Key words: udder casting, milk yield)

Abbreviation key: $\mathbf{A}=$ actual milk volume, $\mathbf{C}=$ calculated milk volume, $\mathbf{C N}=$ calving number, $\mathbf{E U V}=$ empty udder volume, $\mathbf{F U V}=$ full udder volume, $\mathbf{H B I}=$ high breeding index, $\mathbf{L B I}=$ low breeding index, $\mathbf{M Y}=$ milk yield, weeks $=$ weeks in lactation.

Mammary parenchyma productivity is relatively constant, both between and within species, averaging 1.9 $\mathrm{ml} / \mathrm{g}$ per day (Linzell, 1972). Thus, indicators of mammary cell number, such as empty udder weight or volume, are expected to vary proportionally with milk volume. Davis et al. (1983) found that the difference in milk production between Jersey cows with high breeding index (HBI) or low breeding index (LBI) was basically due to differences in udder volume, but in Holstein cows such differences between $\mathrm{H}$ - and L-BI groups depends more on tissue productivity. Nevertheless, in both groups, correlation between udder volume and milk production was significant in all lactation stages. Similarly, cross breed cattle in the tropics present variable udder volume, and this might influence milk pro-

Received June 12, 2002.

Accepted August 16, 2002.

Corresponding author: C. A. Sandoval-Castro; P.O. Box 4-116 Itzimna; e-mail: ccastro@tunku.uady.mx. duction. However, no reports were found in relation to this subject. Several techniques have been used to obtain udder volume in live animals, such as those described by Davis and Hudson (1988) and Dewhurst et al. (1993). The temperament of crossbred cattle do not allow easy implementation of casting techniques, which would require waiting for even a few minutes [we were unable to use the technique described by Dewhurst et al. (1993) due to the length of time needed to prepare the cast, which the animals do not tolerate, as they become uneasy and stressed, jeopardizing operator safety]. Therefore, the objectives of this work were to calibrate a quick yet reliable technique for measuring udder volume, to analyze the relationships between empty udder volume (EUV) and live weight, calving number $(\mathbf{C N})$, daily milk yield (MY) and stage of lactation (week) and to estimate the efficiency of secretion of the mammary parenchyma (L MY/L EUV). This is the first stage in a project studying factors for increasing milk production in this type of cattle in the tropics.

For determination of EUV, aluminum foil was used for udder casting. A double layer of aluminum foil was prepared by estimating the size of sheet for the udder to be measured (with previous observations). Before and after complete milking, cows were restrained in the milking parlor and the aluminum sheet attached to the udder, carefully molding the udder. If necessary, two strips of masking tape were used around the aluminum cast to provide support and to avoid the cast being misshapen. Exogenous oxytocin (10 IU) was used at milking to obtain a totally empty udder. When the cast was ready, polyurethane particles were used for measuring inner volume (L) of the aluminum casts. The technique was calibrated with five dairy cows, at two different milkings each (10 measurements). Differences (L) between full udder volume (FUV) and EUV, were compared with the volume of milk obtained by milking (L) and the relationship assessed via linear regression analysis. The technique was then used to measure EUV of 24 cross-breed cows (Bos taurus $\times B$. indicus), which were milked daily at 0500 and $1500 \mathrm{~h}$. Correlation analysis was performed on EUV, live weight (LW), CN, 


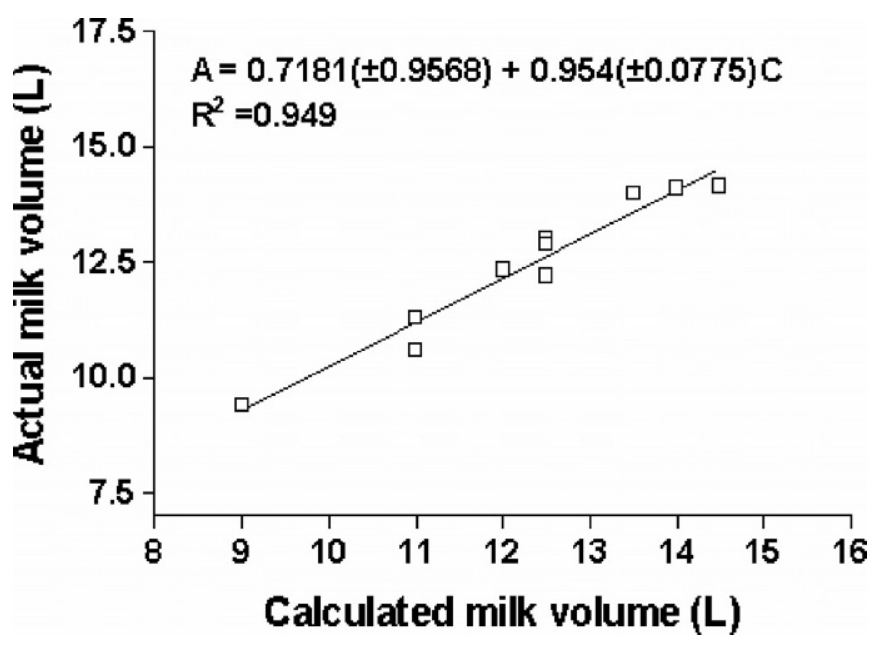

Figure 1. Relationship between calculated milk (C), using an aluminum foil cast, and actual milk volume (A).

weeks in lactation and MY (twice daily milking) (Mead et al., 1993).

Udder casting was done quickly (about $1 \mathrm{~min}$ ) by one person. Thus, minimizing the risk of the operator being hurt by the cow, and also resulting in a reduced stressful condition for the cow. The masking tape gave to the cast the necessary strength to allow the manipulation needed to measure its volume. Summary of data used in the technique calibration was (mean \pm SEM): EUV $=16.8 \pm 0.28, \mathrm{FUV}=29.1 \pm 0.74, \mathrm{FUV}-\mathrm{EUV}=12.3 \pm$ $0.51, \mathrm{MY}=12.4 \pm 0.50$, Difference between estimated udder volume change (FUV-EUV) and actual udder volume change $(\mathrm{MY})=0.149 \pm 0.115$. The difference in the volume obtained before and after milking (FUV-EUV) was closely related $\left(\mathrm{R}^{2}=0.949, P<0.01\right)$ with the volume of milk extracted at milking. Thus, the cast was precise on measuring volumes from 9 to $15 \mathrm{~L}$ (Figure 1).

Significant correlations were found between EUV and MY (Pearson coefficient: 0.514, $P<0.01$ ), $\mathrm{CN}$ and EUV (Pearson coefficient: 0.628, $P<0.001$ ), and MY and week of lactation (Pearson coefficient: $-0.460, P<$ 0.024). All BW relationships were not non-significant
$(P>0.1)$. No significant correlation was found between EUV and week of lactation $(P>0.1)$, and $\mathrm{MY}$ and $\mathrm{CN}$ $(P>0.1)$.

The efficiency of milk secretion obtained from the 24 cows was $1.85 \pm 0.117 \mathrm{ml} / \mathrm{L} \mathrm{EUV}$, similar to the value of $2.053 \pm 0.154$ obtained by Knight and Dewhurst (1994) ( $P>0.35$ when comparing data from both studies with a " $\mathrm{t}$ " test). Using the relationship between EUV (L) and gross udder weight (kg) found by Dewhurst et al. (1993), the secretion efficiency $(\mathrm{ml} / \mathrm{g})$ from both studies was estimated in $1.97 \pm 0.125$ and $2.17 \pm 0.163$, respectively, values, which closely match the mammary parenchyma productivity reported by Linzell (1972) at $1.9 \mathrm{ml} / \mathrm{g}$ per day. These values, and the relationship found between EUV and MY, suggest that those animals with more mammary tissue would have greater milk production. Thus, in tropical systems, improvement of mammary development could increase milk production. However, an indicator would be needed to estimate the number of secretory cells and(or) the udder's cisternal:alveolar relationship if an appropriate selection is to be made, otherwise selecting for EUV alone might not be related to increased milk yield.

Casting of udder with aluminum foil is a simple yet reliable technique to measure udder volume.

\section{REFERENCES}

Davis, S. R., and G. A. Hughson. 1988. Measurement of functional udder capacity in lactating jersey cows. Aust. J. Agric. Res. 39:1163-1168.

Davis, S. R., G. A. Hughson, A. M. Bryant, and D. D. S. Mackenzie. 1983. Differences in the extent of mammary development between Jersey cows of high or low genetic merit. Proc. N.Z. Soc. Anim. Prod. 45:21-26.

Dewhurst, R. J., A. M. Mitton, and C. H. Knight. 1993. Calibration of a polyurethane foam casting technique for estimating the weight of bovine udders Anim. Prod. 56:444. (Abstr.)

Knight, C. H., and R. J. Dewhurst. 1994. Once daily milking of dairy cows: relationship between yield loss and cisternal milk storage. J. Dairy Res. 61:441-449.

Linzell, J. L. 1972. Milk yield, energy loss in milk and mammary gland weight in different species. Dairy Sci. Abstr. 34:351-360.

Mead, R., R. N. Curnow, and A. M. Hasted. 1993. Statistical Methods in Agriculture and Experimental Biology. 2nd ed. Chapman \& Hall, London. 